\title{
Construction of a Novel Potentiometric Terbium(III) Membrane Sensor and its Application for the Determination of Terbium Ion in Binary Mixture and Fluoride Ion in a Mouth Wash Preparation
}

\author{
Hassan Ali Zamani, ${ }^{*, a}$ Ghadir Rajabzadeh $^{a}$ and Mohammad Reza Ganjali ${ }^{b}$ \\ ${ }^{a}$ Department of Chemistry, Quchan branch, Islamic Azad University, Quchan, Iran \\ ${ }^{b}$ Department of Chemistry, Tehran University, Tehran, Iran
}

\begin{abstract}
Um novo sensor potenciométrico constituído por uma membrana de PVC, altamente seletivo a íons Tb(III) foi preparado usando-se 4-amino-3-\{2-[4-amino-6-metil-5-oxo-4,5-diidro-1,2,4triazina-3(2H)-ilidina] hidrazono -6-metil-3,4-diidro-1,2,4-triazina-5(2H)-ona (ATO) como um carregador adequado. $\mathrm{O}$ sensor trabalha satisfatoriamente no intervalo de concentração de $1,0 \times$ $10^{-6}$ a $1,0 \times 10^{-1} \mathrm{~mol} \mathrm{~L}^{-1}$ (limite de detecção $8,6 \times 10^{-7} \mathrm{~mol} \mathrm{~L}^{-1}$ ) com uma inclinação Nernstiniana de $19,4 \pm 0.5 \mathrm{mV}$ per década de atividade. O eletrodo mostrou rápido tempo de resposta $(\sim 15 \mathrm{~s})$ e foi usado por um período superior a 2 meses. Os valores do coeficiente de seletividade potenciométrica (para cátions mono-, di-, e trivalentes) como determinado pelo método match potential (MPM) indicou boa resposta para $\mathrm{Tb}^{3+}$ na preseça de íons interferentes. A membrana sensora foi usada como um eletrodo indicador na titulação potenciométrica de íons $\mathrm{Tb}(\mathrm{III})$ com EDTA. Foi também aplicado na determinação de íons fluoreto em amostras de preparados para enxágue bucal e na recuperação de $\mathrm{Tb}^{3+}$ de várias misturas binárias.
\end{abstract}

A new PVC membrane potentiometric sensor that is highly selective to $\mathrm{Tb}(\mathrm{III})$ ions was prepared by using 4-amino-3-\{2-[4-amino-6-methyl-5-oxo-4,5-dihydro-1,2,4-triazin-3(2H)-yliden] hydrazono -6-methyl-3,4-dihydro-1,2,4-triazin-5(2H)-one (ATO) as a suitable carrier. The sensor works satisfactorily in the concentration range of $1.0 \times 10^{-6}$ to $1.0 \times 10^{-1} \mathrm{~mol} \mathrm{~L}^{-1}$ (detection limit $\left.8.6 \times 10^{-7} \mathrm{~mol} \mathrm{~L}^{-1}\right)$ with a Nernstian slope of $19.4 \pm 0.5 \mathrm{mV}$ per decade of activity. This electrode showed a fast response time $(\sim 15 \mathrm{~s})$ and was used for a period of more than 2 months. The potentiometric selectivity coefficient values (for mono-, di-, and trivalent cations) as determined by the match potential method (MPM) indicate good response for $\mathrm{Tb}^{3+}$ in the presence of interfering ions. The membrane sensor was used as an indicator electrode in the potentiometric titration of $\mathrm{Tb}(\mathrm{III})$ ions with EDTA. It was also applied to the determination of fluoride ions in mouth wash preparation sample and the $\mathrm{Tb}^{3+}$ recovery from various binary mixtures.

Keywords: 4-amino-3-\{2-[4-amino-6-methyl-5-oxo-4,5-dihydro-1,2,4-triazin-3(2H)-yliden] hydrazono $\}-6$-methyl-3,4-dihydro-1,2,4-triazin-5(2H)-one, terbium, potentiometry, ion-selective electrode

\section{Introduction}

The rare-earth industry is growing and the average increase over the past years has been $5-15 \%$. The rare earths are considered only slightly toxic according to the Hodge-Sterner classification system and thus can be handled safely with ordinary care. Similar to, the other lanthanides, terbium compounds are low to moderate toxicity, although their toxicity has not been investigated in detail. ${ }^{1}$ When rare-earth vapors or dust are inhaled, they

*e-mail: zamani_has2000@yahoo.com are somewhat more toxic but tend to remain in the lungs and are only slowly absorb into the body. ${ }^{2}$ Terbium has no known biological role. High purity individual lanthanides are used increasingly as major components in laser, phosphors, magnetic bubble memory films, refractive index lenses, fiber optics and superconductors. ${ }^{3}$ The main applications include; firstly, the use of mixed rare-earth as gasoline-cracking catalysts, and as starting materials for making misch metal, secondly, the use of rare-earth silicides for various metallurgical applications as polishing compounds, and for carbon arcs used in movie projectors and searchlights. ${ }^{1}$ 
Many techniques have been used for the determination of terbium. Most of them belong to spectroscopic methods such as ICP-MS, electron spin resonance, high resolution $\gamma$-spectroscopy atomic emission spectroscopy, spectrophotofluorimetric, laser-based multi step resonance ionization and some nucleic methods. But all of these methods are either time consuming, involving multiple sample manipulations or they are too expensive for most analytical laboratories. As a result, it is valuable to find an inexpensive and simple technique, which can provide the selectivity that is necessary to determine terbium in the presence of other lanthanides that are very similar to terbium. However, a simple method that offers great advantages such as speed and eases of preparation and procedures, relatively short response times, reasonable selectivity, wide linear dynamic ranges, and low cost, is the potentiometric detections which is based on ion-selective sensors. The above mentioned may be the reason for the interest that has led to the development of electrodes for several ionic species. Therefore the list of the available sensors has hence, grown substantially over the past years. ${ }^{4}$

There have been many studies on ion-selective electrodes for transition and heavy metal ions. ${ }^{5}$ Among these metal ions a little attention has been paid to the development of lanthanide electrodes. ${ }^{6-23}$ There is just one report on the determination of terbium using ion selective electrode with a narrow dynamic range (from $1.0 \times 10^{-5}$ to $\left.0.10 \mathrm{~mol} \mathrm{~L}^{-1}\right)$ and high detection limit $\left(7.0 \times 10^{-6} \mathrm{~mol}\right.$ $\left.\mathrm{L}^{-1}\right) .{ }^{18}$ We have recently reported a number of sensors for some ions such as $\mathrm{Zn}(\mathrm{II}),{ }^{24,25} \mathrm{Ca}(\mathrm{II}),{ }^{26} \mathrm{Cu}(\mathrm{II}),{ }^{27,28} \mathrm{SCN}^{-},{ }^{29}$ $\mathrm{Cr}(\mathrm{III}),{ }^{30} \mathrm{Ba}(\mathrm{II}) .{ }^{31}$ In this work, we report a $\mathrm{Tb}(\mathrm{III})$ membrane sensor based on 4-Amino-3-\{2-[4-amino-6methyl-5-oxo-4,5-dihydro-1,2,4-triazin-3(2H)-yliden] hydrazono $\}$-6-methyl-3,4-dihydro-1,2,4-triazin-5(2H)one (Figure 1) with a Nernstian response over a relatively wide working range.

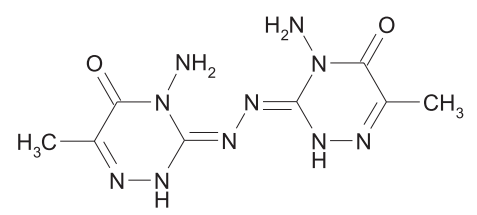

Figure 1. Structure of 4-amino-3-\{2-[4-amino-6-methyl-5-oxo-4,5dihydro-1,2,4-triazin-3(2H)-yliden] hydrazono $\}$-6-methyl-3,4-dihydro1,2,4-triazin-5(2H)-one (ATO).

\section{Experimental}

\section{Reagents and materials}

Reagent grade 2-nitrophenyl octyl ether (NPOE), dibutyl phthalate (DBP), nitrobenzene (NB), sodium tetraphenyl borate (NaTPB), tetrahydrofuran (THF) and high relative molecular weight PVC were purchased from Merck and Aldrich, used as received. The nitrate and chloride salts of all cations used (all from Merck and Aldrich) were of the highest purity available and used without any further purification except for vacuum drying over $\mathrm{P}_{2} \mathrm{O}_{5}$. Triply distilled de-ionized water was used throughout the experiment.

\section{Ionophore ATO synthesis}

4-Amino-3-hydrazono-6-methyl-1,2,4-triazin-5 (2H, $4 \mathrm{H}$ )-one (1560 mg, $10 \mathrm{mmol}$ ) dissolved in $n$-butanol (15 $\mathrm{mL})$. Hydrazinhydrate $80 \%(1 \mathrm{~mL})$ was added drop wise to the boiling solution in a period of $1 \mathrm{~h}$. The resulting precipitates were filtered off and washed with hot ethanol to afford the title compound. Yield: $812 \mathrm{mg}(58 \%)$; mp $290{ }^{\circ} \mathrm{C} ;{ }^{1} \mathrm{H}-\mathrm{NMR} \times\left(d_{6}\right.$-DMSO $), \mathrm{ppm}: 11.8(\mathrm{~s}, 1 \mathrm{H}, \mathrm{NH})$, $6.1\left(\mathrm{~s}, 2 \mathrm{H}, \mathrm{NH}_{2}\right), 2.2\left(\mathrm{~s}, 3 \mathrm{H}, \mathrm{CH}_{3}\right)$; IR ( $\mathrm{KBr}$ disc) $\mathrm{v}_{\max } / \mathrm{cm}^{-1}: 3260\left(\mathrm{NH}_{2}\right.$ st., free), $3180\left(\mathrm{NH}_{2}\right.$ st., H-bond), 2980 (C-H st.), 1680 (carbonyl st.), 1625, 1560 (ring deformation), 1195 (C-N st.), 1120, 920; MS, m/z: 280 $\left(\mathrm{M}^{+}, 3\right), 279$ (M-1, 41), 278 (100), 277 (97), 247 (14), 220 (88), 219 (52), 195 (17), 180 (18), 151 (10), 140 (54), 112 (25), 82 (61), 69 (68), 57 (98), 43 (93), 42 (94), 41 (32), 31 (50), 29 (51), 28 (95).

\section{EMF measurements}

All EMF measurements were carried out with the following cell assembly:

$\mathrm{Ag} / \mathrm{AgCl} \mid$ internal solution, $\left(1 \times 10^{-3} \mathrm{~mol} \mathrm{~L}^{-1} \mathrm{TbCl}_{3}\right) \mid$ PVC membrane | sample solution $\mid \mathrm{Hg}_{2} \mathrm{Cl}_{2}, \mathrm{KCl}$ (saturated).

A Corning ion analyzer $250 \mathrm{pH} / \mathrm{mV}$ meter was used for potential measurements at $25.0 \pm 0.1{ }^{\circ} \mathrm{C}$. Activities were calculated according to Debye-Huckel procedure. ${ }^{32}$

\section{Preparation of the electrode}

Membrane solutions were prepared by thoroughly dissolving $5.5 \mathrm{mg}$ of the ATO ionophore, $30 \mathrm{mg}$ of powdered PVC, $3.5 \mathrm{mg}$ of additive NaTPB and $61 \mathrm{mg}$ of plasticizer DBP in $3 \mathrm{~mL}$ of THF. The resulting clear mixture was evaporated slowly until an oily concentrated mixture was obtained. A Pyrex tube (5 mm o.d.) was dipped into the mixture for $\sim 10 \mathrm{~s}$, so that a transparent membrane $0.3 \mathrm{~mm}$ thick was formed. The membrane thickness and the inner tube diameter were optimized in previous papers. ${ }^{20-27,33,34}$ The tube was then pulled out from the mixture and kept at room temperature for $12 \mathrm{~h}$. The tube was then filled with an internal solution $\left(1.0 \times 10^{-3} \mathrm{~mol} \mathrm{~L}^{-1} \mathrm{TbCl}_{3}\right)$. The electrode was finally conditioned for $36 \mathrm{~h}$ by soaking in a $1.0 \times 10^{-2}$ 
mol L $\mathrm{L}^{-1}$ terbium chloride solution. A silver/silver chloride electrode or a silver/silver chloride-coated wire was used as the internal reference electrode.

\section{Results and Discussion}

\section{Potential response of the electrode based on ATO}

It was found that the plasticized PVC-based membrane containing ATO (with ten nitrogen and two oxygen donor atoms in its structure) as a neutral ionophore, generated stable potentials in solutions containing the terbium ion, after proper conditioning in a $1.0 \times 10^{-2} \mathrm{~mol} \mathrm{~L}^{-1}$ solution of $\mathrm{TbCl}_{3}$. The membranes showed remarkable selectivity for $\mathrm{Tb}^{3+}$ compared with the most common metal ions. For this purpose, in preliminary experiments, ATO was used as a neutral carrier to prepare plasticized polymeric membrane for a variety of alkali, alkaline earth, transition and heavy metal ions. The potential responses of some of the most sensitive electrodes based on ATO are shown in Figure 2 (a, b). As it is obvious from Figure 2, among different cations tested, $\mathrm{Tb}$ (III) with the most sensitive response seems to be suitably determined with the electrode in the concentration range of $1.0 \times 10^{-6}$ $1.0 \times 10^{-1} \mathrm{~mol} \mathrm{~L}^{-1}$. This is due to the selective behavior of the PVC membrane system against $\mathrm{Tb}$ (III) in comparison with other metal ions. Due to the existence of a semi cavity with four donor nitrogen atoms in the structure of ATO, it can form relatively strong complex with transition metal ions, and especially lanthanide metal ions. Among the lanthanide metal ions with different size, charge density and hydration energy, terbium ion in the middle of this group, forms more stable complex with ATO.

The membrane composition effect on the potential response of the $T b(I I I)$ sensor

It is well known that the selectivity and sensitivity of the ion-selective sensors depend on the membrane
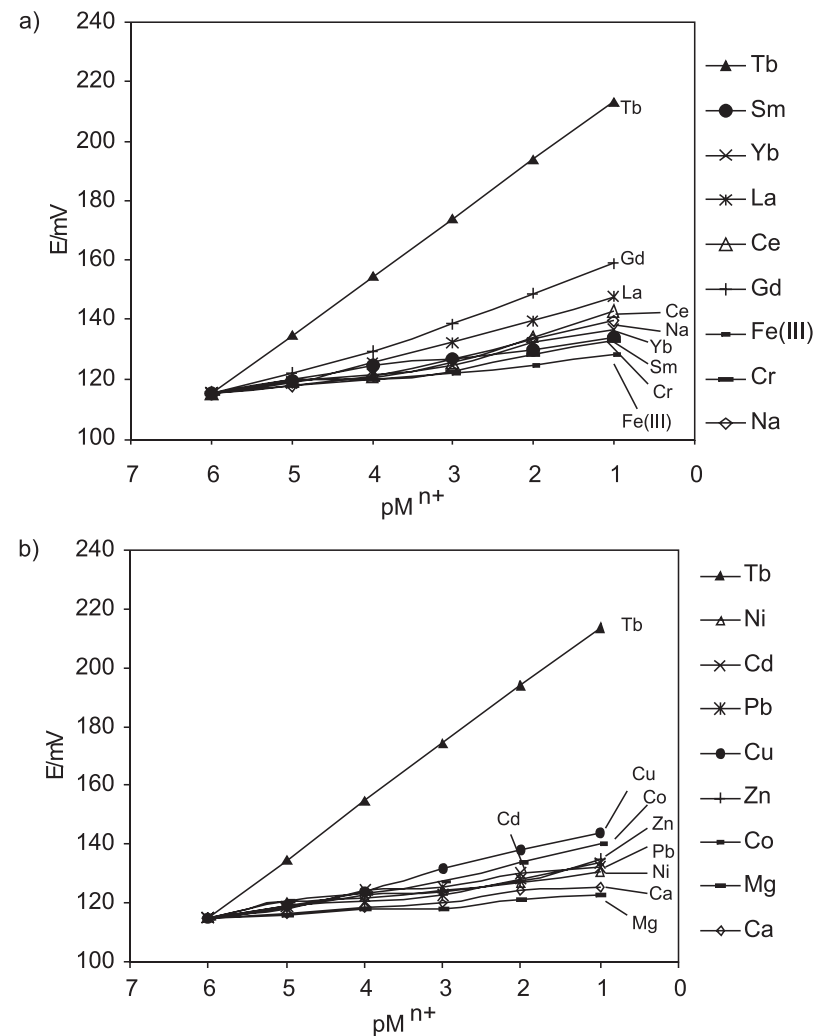

Figure 2. The potential responses of the various ion-selective electrodes based on ATO (membrane no. 8) in the concentration range of $1.0 \times 10^{-1}$ $1.0 \times 10^{-6} \mathrm{~mol} \mathrm{~L}^{-1}$.

composition significantly, the nature of the employed ATO and the nature of the solvent mediator and additives used. ${ }^{5,24-31}$ Thus, the influences of the membrane composition, the nature and the amount of plasticizer and the amount of sodium tetraphenylborate as lipophilic additives on the potential response of the terbium electrodes were investigated. The corresponding results are summarized in Table 1. It is seen that the membrane [No. $8]$ with the optimized compositions of 5.5\% ionophore and $61 \%$ DBP in the presence of 30\% PVC and 3.5\% NaTPB results in the best sensitivity with Nernstian slopes of 19.4

Table 1. Optimization of membrane ingredients

\begin{tabular}{|c|c|c|c|c|c|c|}
\hline \multirow[t]{2}{*}{ Electrode No. } & \multicolumn{4}{|c|}{ Composition / (wt\%) } & \multirow{2}{*}{$\begin{array}{c}\text { Slope / } \\
\left(\mathrm{mV} \mathrm{decade}{ }^{-1}\right)\end{array}$} & \multirow{2}{*}{$\begin{array}{l}\text { Concentration } \\
\text { range / }\left(\mathrm{mol} \mathrm{L}^{-1}\right)\end{array}$} \\
\hline & ATO & NaTPB & Plasticizer & PVC & & \\
\hline 1 & 2 & 1 & DBP, 67 & 30 & $10.1 \pm 0.3$ & $1.0 \times 10^{-4}-1.0 \times 10^{-1}$ \\
\hline 2 & 4 & 1 & DBP, 65 & 30 & $13.6 \pm 0.5$ & $1.0 \times 10^{-4}-1.0 \times 10^{-1}$ \\
\hline 3 & 6 & 1 & DBP, 63 & 30 & $11.8 \pm 0.2$ & $1.0 \times 10^{-4}-1.0 \times 10^{-1}$ \\
\hline 4 & 5 & 1 & DBP, 64 & 30 & $12.5 \pm 0.6$ & $1.0 \times 10^{-4}-1.0 \times 10^{-1}$ \\
\hline 5 & 5.5 & 1 & DBP, 63.5 & 30 & $14.9 \pm 0.5$ & $1.0 \times 10^{-5}-1.0 \times 10^{-1}$ \\
\hline 6 & 5.5 & 2 & DBP, 62.5 & 30 & $16.7 \pm 0.4$ & $1.0 \times 10^{-6}-1.0 \times 10^{-1}$ \\
\hline 7 & 5.5 & 3 & DBP, 61.5 & 30 & $18.3 \pm 0.7$ & $1.0 \times 10^{-6}-1.0 \times 10^{-1}$ \\
\hline 8 & 5.5 & 3.5 & DBP, 61 & 30 & $19.4 \pm 0.5$ & $1.0 \times 10^{-6}-1.0 \times 10^{-1}$ \\
\hline 9 & 5.5 & 3.5 & NPOE, 61 & 30 & $17.8 \pm 0.6$ & $1.0 \times 10^{-6}-1.0 \times 10^{-1}$ \\
\hline 10 & 5.5 & 3.5 & $\mathrm{NB}, 61$ & 30 & $16.7 \pm 0.3$ & $1.0 \times 10^{-6}-1.0 \times 10^{-1}$ \\
\hline
\end{tabular}


$\pm 0.5 \mathrm{mV}$ decade $^{-1}$ over wide dynamic ranges. As it is obvious from Table 1, the presence of 3.5\% NaTPB, gave the provided the electrode with Nernstian potential responses. In fact, it has been demonstrated that the presence of lipophilic negatively charged additives such as NaTPB improves the potentiometric behavior of certain selective electrodes, not only by reducing the ohmic resistance and improving the response behavior and selectivity but also, in cases where the extraction capability of the ionophore is poor, by enhancing the sensitivity of the membrane electrodes. ${ }^{35-37}$

For the investigation of the potential response of the sensor to the common anions, a number of soluble salts of sodium ion including $\mathrm{NaCl}, \mathrm{NaNO}_{3}, \mathrm{NaCH}_{3} \mathrm{COO}$, $\mathrm{Na}_{2} \mathrm{SO} 4, \mathrm{NaHCO}_{3}, \mathrm{NaH}_{2} \mathrm{PO}_{4}, \mathrm{NaBr}, \mathrm{NaI}$ and $\mathrm{NaClO}_{4}$ were chosen and their potential responses were measured. The results showed that the responses of these common anions were very weak.

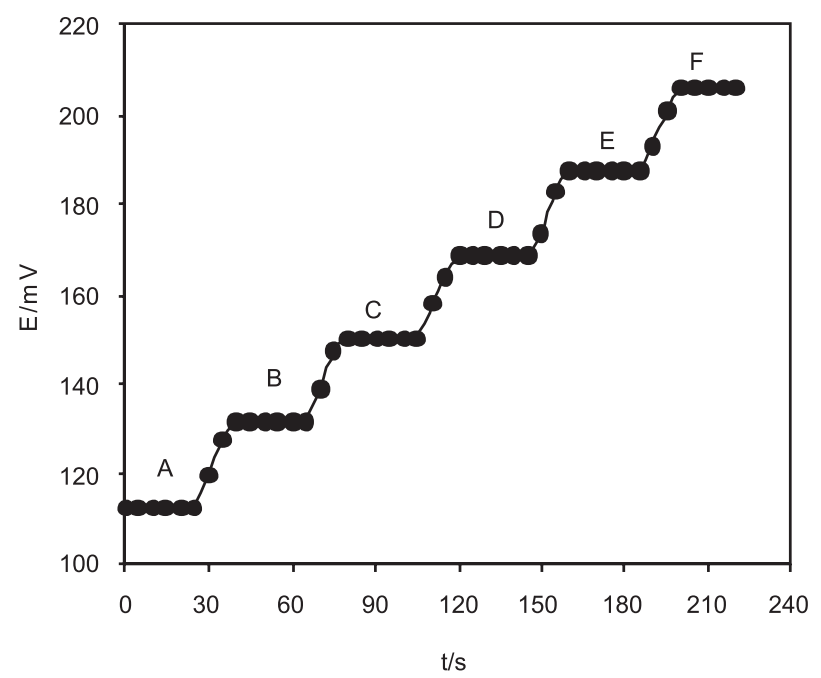

Figure 3. Dynamic response time of the ATO membrane sensor for step changes in the concentration of $\mathrm{Tb}^{3+}$ : A) $1.0 \times 10^{-6} \mathrm{~mol} \mathrm{~L}^{-1}$, B) $1.0 \times 10^{-5}$ mol L ${ }^{-1}$, C) $1.0 \times 10^{-4} \mathrm{~mol} \mathrm{~L}^{-1}$, D) $1.0 \times 10^{-3} \mathrm{~mol} \mathrm{~L}^{-1}$, E) $1.0 \times 10^{-2} \mathrm{~mol} \mathrm{~L}^{-1}$, F) $1.0 \times 10^{-1} \mathrm{~mol} \mathrm{~L}^{-1}$.

\section{Response time}

Dynamic response time is an important factor for any ion selective electrodes. In this study, the practical response time of the sensor was recorded by changing the solution with different $\mathrm{Tb}^{3+}$ concentrations from $1.0 \times 10^{-6}$ to $1.0 \times 10^{-1} \mathrm{~mol} \mathrm{~L}^{-1}$. The actual potential versus time trace for the electrode based on ATO is shown in Figure 3. As it can be seen, the electrode reaches its equilibrium response in a short time of about $15 \mathrm{~s}$. This is most probably due to the fast exchange kinetics of complexation-decomplexation of $\mathrm{Tb}^{3+}$ ion with the ionophore at the test solution membrane interface.

\section{Calibration plot and statistical data}

The potential responses of the proposed sensors at varying concentration of $\mathrm{Tb}(\mathrm{III})$ ion show a linear response to the concentration of $\mathrm{Tb}^{3+}$ ions in the range of $1.0 \times 10^{-6}$ $1.0 \times 10^{-1} \mathrm{~mol} \mathrm{~L}^{-1}$ (Figure 4). The slopes of the calibration plots were $19.4 \pm 0.5 \mathrm{mV}$ decade ${ }^{-1}$ of the $\mathrm{Tb}^{3+}$ ions activity. The detection limit as determined from the intersection of the two extrapolated segments of the calibration plots were $8.6 \times 10^{-7} \mathrm{~mol} \mathrm{~L}^{-1}$. The standard deviation of 9 replicate measurements was $\pm 0.4 \mathrm{mV}$. The membrane electrodes prepared could be used for at least 2 months without any measurable divergence.

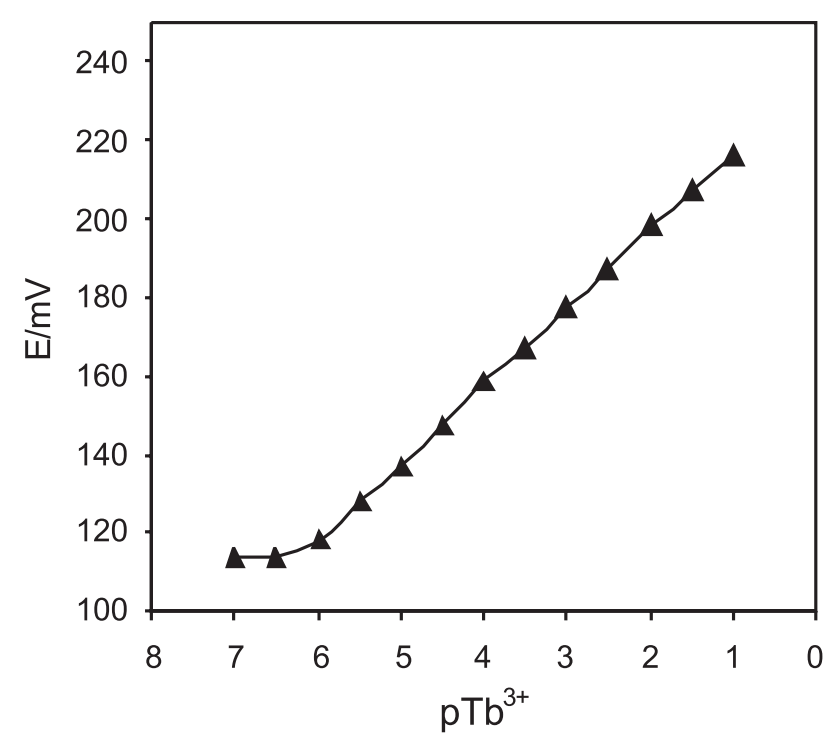

Figure 4. Calibration curve of the $\mathrm{Tb}^{3+}$ sensor based on ATO (membrane no. 8 ).

pH effect

The $\mathrm{pH}$ influence of the test solution (containing 1.0 $\times 10^{-3}$ and $1.0 \times 10^{-2} \mathrm{~mol} \mathrm{~L}^{-1}$ of $\mathrm{Tb}^{3+}$ ions) on the potential responses of the three membrane sensors was tested in the $\mathrm{pH}$ range of $1.5-11.0$ and the results summarized in Figure 5. Evidently, potentials remain constant over a $\mathrm{pH}$ range of $3.8-8.2$. At the lower and higher $\mathrm{pH}$ values, the potential changes sharply. The observed drifts at lower and higher $\mathrm{pH}$ values could be attributed to the protonation of the ionophore and the formation of some hydroxyl complexes of $\mathrm{Tb}^{3+}$ ions in solution, respectively.

\section{Potentiometric selectivity}

The potentiometric selectivity coefficients, which reflect the relative response of the membrane sensor for the primary ion over other ions that are present in solution, are perhaps the most important characteristics of an ion-selective 


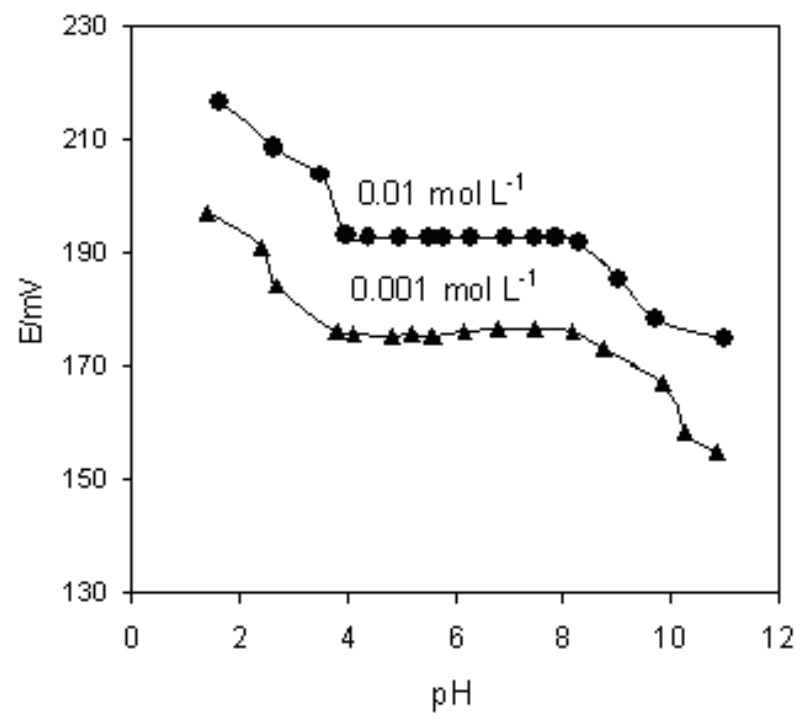

Figure 5. The effect of the $\mathrm{pH}$ of the test solution $\left(1.0 \times 10^{-3} \mathrm{~mol} \mathrm{~L}^{-1}\right.$ of $\left.\mathrm{Tb}^{3+}\right)$ on the potential response of the terbium sensor based on ATO (membrane No. 8).

electrode. In this work, the potential response of the proposed $\mathrm{Tb}^{3+}$ ion-selective sensors compared with most common metal ions was investigated by the match potential method (MPM).$^{38}$ According to the MPM, the selectivity coefficient is defined as the activity ratio of the primary ion (A) and the interfering ion (B) that gives the some potential change in a reference solution. The resulting values are shown in Table 2. As it is seen, for all diverse ions used, the selectivity coefficients are in the order of $10^{-3}$ or smaller, indicating they would not significantly disturb the function, of the proposed $\mathrm{Tb}(\mathrm{III})$ membrane sensor.

Table 2. Selectivity coefficients of the electrode

\begin{tabular}{lccc}
\hline $\mathrm{M}^{\mathrm{n+}}$ & $\mathrm{K}_{\mathrm{Tb}^{\mathrm{M}}, \mathrm{B}}^{\mathrm{MM}}$ & $\mathrm{M}^{\mathrm{n+}}$ & $\mathrm{K}_{\mathrm{Tb}^{3+}, \mathrm{B}}^{\mathrm{MM}}$ \\
\hline $\mathrm{Yb}^{3+}$ & $1.0 \times 10^{-3}$ & $\mathrm{Cd}^{2+}$ & $8.8 \times 10^{-4}$ \\
$\mathrm{Gd}^{3+}$ & $7.5 \times 10^{-3}$ & $\mathrm{Cu}^{2+}$ & $3.7 \times 10^{-3}$ \\
$\mathrm{Sm}^{3+}$ & $8.6 \times 10^{-4}$ & $\mathrm{Ni}^{2+}$ & $8.1 \times 10^{-4}$ \\
$\mathrm{Ce}^{3+}$ & $1.3 \times 10^{-3}$ & $\mathrm{Co}^{2+}$ & $1.0 \times 10^{-3}$ \\
$\mathrm{La}^{3+}$ & $3.4 \times 10^{-3}$ & $\mathrm{Zn}^{2+}$ & $7.2 \times 10^{-4}$ \\
$\mathrm{Cr}^{3+}$ & $7.8 \times 10^{-4}$ & $\mathrm{Na}^{+}$ & $1.0 \times 10^{-3}$ \\
$\mathrm{Fe}^{3+}$ & $6.8 \times 10^{-4}$ & $\mathrm{Mg}^{2+}$ & $4.2 \times 10^{-4}$ \\
$\mathrm{~Pb}^{2+}$ & $9.0 \times 10^{-4}$ & $\mathrm{Ca}^{2+}$ & $5.6 \times 10^{-4}$ \\
\hline
\end{tabular}

In Table 3, the major interfering ions (just a gross relative comparison), dynamic linear range, the detection limit and response time of the proposed electrode are compared with the best data of the previously reported $\mathrm{Tb}$ (III) selective membrane electrode. It is immediately obvious that the proposed $\mathrm{Tb}$ (III) sensor in terms of selectivity coefficients, dynamic linear range, detection limit and response time is superior to the previously $\mathrm{Tb}(\mathrm{III})$ ion-selective electrode. ${ }^{18}$
Table 3. Comparison of the selectivity coefficients, linearity range, detection limit and response time of proposed $\mathrm{Tb}$ (III) electrode and the previously reported $\mathrm{Tb}(\mathrm{III}) \mathrm{PVC}-\mathrm{membrane}$ sensors

\begin{tabular}{|c|c|c|}
\hline & \multicolumn{2}{|c|}{ Selectivity coefficients } \\
\hline & $\begin{array}{c}\text { Reference } 26 \\
\text { MPM }\end{array}$ & $\begin{array}{l}\text { This work } \\
\text { MPM }\end{array}$ \\
\hline$\overline{\mathrm{Yb}^{3+}}$ & $4.32 \times 10^{-2}$ & $1.0 \times 10^{-3}$ \\
\hline $\mathrm{Gd}^{3+}$ & $7.91 \times 10^{-3}$ & $7.5 \times 10^{-3}$ \\
\hline $\mathrm{Sm}^{3+}$ & $2.51 \times 10^{-2}$ & $8.6 \times 10^{-4}$ \\
\hline $\mathrm{Ce}^{3+}$ & $1.32 \times 10^{-2}$ & $1.3 \times 10^{-3}$ \\
\hline $\mathrm{La}^{3+}$ & $1.58 \times 10^{-2}$ & $3.4 \times 10^{-3}$ \\
\hline $\mathrm{Cr}^{3+}$ & $\ldots$ & $7.8 \times 10^{-4}$ \\
\hline $\mathrm{Fe}^{3+}$ & - & $6.8 \times 10^{-4}$ \\
\hline $\mathrm{Pb}^{2+}$ & $6.30 \times 10^{-3}$ & $9.0 \times 10^{-4}$ \\
\hline $\mathrm{Cd}^{2+}$ & - & $8.8 \times 10^{-4}$ \\
\hline $\mathrm{Cu}^{2+}$ & $7.90 \times 10^{-3}$ & $3.7 \times 10^{-3}$ \\
\hline $\mathrm{Ni}^{2+}$ & $3.50 \times 10^{-3}$ & $8.1 \times 10^{-4}$ \\
\hline $\mathrm{Co}^{2+}$ & $4.20 \times 10^{-3}$ & $1.0 \times 10^{-3}$ \\
\hline $\mathrm{Zn}^{2+}$ & $\ldots$ & $7.2 \times 10^{-4}$ \\
\hline $\mathrm{Na}^{+}$ & - & $1.0 \times 10^{-3}$ \\
\hline $\mathrm{Mg}^{2+}$ & - & $4.2 \times 10^{-4}$ \\
\hline $\mathrm{Ca}^{2+}$ & $\ldots$ & $5.6 \times 10^{-4}$ \\
\hline Response time / (s) & $\overline{<20}$ & $\sim 15$ \\
\hline $\begin{array}{l}\text { Linearity range / } \\
\left(\mathrm{mol} \mathrm{L}^{-1}\right)\end{array}$ & $1.0 \times 10^{-5}-1.0 \times 10^{-1}$ & $1.0 \times 10^{-6}-1.0 \times 10^{-1}$ \\
\hline $\begin{array}{l}\text { Limit of detection / } \\
\left(\mathrm{mol} \mathrm{L}^{-1}\right)\end{array}$ & $7.0 \times 10^{-6}$ & $8.6 \times 10^{-7}$ \\
\hline
\end{tabular}

\section{Analytical applications}

The proposed sensor works well under laboratory conditions and can be successfully employed as an indicator electrode in the potentiometric titrations of $\mathrm{Tb}^{3+}$ $\left(1.0 \times 10^{-4} \mathrm{~mol} \mathrm{~L}^{-1}\right)$ with a standard EDTA solution $(1.0 \times$ $\left.10^{-2} \mathrm{~mol} \mathrm{~L}^{-1}\right)$. The respective titration curve is shown in Figure 6. Obviously, the amount of $\mathrm{Tb}^{3+}$ ions in solution can be determined with the electrode.

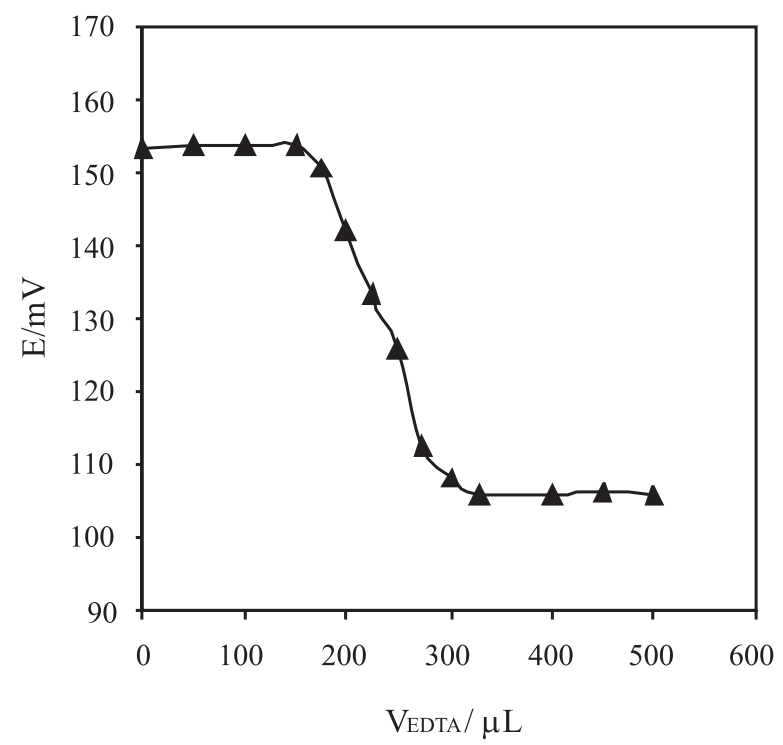

Figure 6. Potentiometric titration curve of $25.0 \mathrm{~mL}$ of a $1.0 \times 10^{-4} \mathrm{~mol} \mathrm{~L}^{-1}$ solution of $\mathrm{Tb}^{3+}$ with $1.0 \times 10^{-2} \mathrm{~mol} \mathrm{~L}^{-1}$ of EDTA standard solution. 
The membrane sensor was used for the fluoride ion determination in a mouth wash preparation sample (Aquafresh, Brentford, U.K.). $1.0 \mathrm{~g}$ of each sample was taken and diluted with distilled water in a $100 \mathrm{~mL}$ flask and titrated with a $\mathrm{Tb}^{3+}$ solution $\left(1.0 \times 10^{-3} \mathrm{~mol} \mathrm{~L}^{-1}\right)$ and the results of the triplicate measurements are summarized in Table 4. As it is seen, there is a satisfactory agreement among the declared fluoride content, the determined values by the sensor and the commercial solid fluoride sensor (ELIT 101).

Table 4. Determination of fluoride ions in mouth wash solution

\begin{tabular}{lccc}
\hline Sample & $\begin{array}{c}\text { Labeled / } \\
\left(\mathrm{mg} \mathrm{mL}^{-1}\right)\end{array}$ & $\begin{array}{c}\text { Found ISE } / \\
\left(\mathrm{mg} \mathrm{mL}^{-1}\right)\end{array}$ & $\begin{array}{c}\text { Commercial } \\
\text { Flouride ISE / } \\
\left(\mathrm{mg} \mathrm{mL}^{-1}\right)\end{array}$ \\
\hline
\end{tabular}

Sodium fluoride mouth

wash solution

(Aquafresh, Brentford, U.K.) $\quad 1.35 \quad\left(1.38^{\mathrm{b}} \pm 0.03\right)\left(1.33^{\mathrm{b}} \pm 0.01\right)$

aProposed $\mathrm{Tb}^{3+}$ sensor; ${ }^{\mathrm{b}}$ Results are based on three measurements.

Because of the high selectivity and the low detection limit of the proposed $\mathrm{Tb}$ (III) sensor, it was additionally, applied for the monitoring of the $\mathrm{Tb}$ (III) ions concentration of in various binary mixtures. These results are listed in Table 5 , demonstrating that the recoveries of the $\mathrm{Tb}(\mathrm{III})$ ions in all mixtures are acceptable and in the range of 98.6-102.3\%.

Table 5. Recovery of $\mathrm{Tb}(\mathrm{III})$ ions from binary mixtures by the proposed $\mathrm{Tb}(\mathrm{III})$ ion-selective electrode

\begin{tabular}{lcc}
\hline $\mathrm{Tb}(\mathrm{III}) /(\mathrm{ppm})$ & Added cation / (ppm) & Recovery / (\%) \\
\hline 20 & $\mathrm{Yb}^{3+}, 100$ & $99.6^{\mathrm{a}} \pm 0.3$ \\
20 & $\mathrm{Gd}^{3+}, 100$ & $102.3 \pm 0.5$ \\
20 & $\mathrm{Sm}^{3+}, 100$ & $101.8 \pm 0.9$ \\
20 & $\mathrm{La}^{3+}, 100$ & $98.6 \pm 0.4$ \\
20 & $\mathrm{~Pb}^{2+}, 100$ & $101.3 \pm 0.8$ \\
20 & $\mathrm{Cu}^{2+}, 100$ & $99.3 \pm 0.7$ \\
20 & $\mathrm{Ni}^{2+}, 100$ & $102.3 \pm 0.4$ \\
20 & $\mathrm{Co}^{2+}, 100$ & $99.7 \pm 0.5$ \\
20 & $\mathrm{Na}^{+}, 100$ & $101.8 \pm 0.6$ \\
20 & $\mathrm{Ca}^{2+}, 100$ & $102.1 \pm 0.4$ \\
\hline
\end{tabular}

aResults are based on three measurements.

\section{Acknowledgments}

The authors express their appreciation to the Research Council of the University of Quchan for the financial support of this work.

\section{References}

1. Kirk, O. R.; Othmer, F. D.; Encyclopedia of Chemical Technology, Wiley: New York, 1982, vol. 19, p. 836.
2. Haiduc, I.; Silvestru, C.; Coord. Chem. Rev. 1990, 99, 253.

3. Kirk, O. R.; Othmer, F. D.; Encyclopedia of Chemical Technology, Wiley: New York, 1982, vol. 19, p. 851.

4. Buhlmann, P.; Pretsch, E.; Bakker, E.; Chem. Rev. 1998, 98, 1593.

5. Bakker, E.; Bühlmann, P.; Pretsch, E.; Chem. Rev. 1997, 97, 3083.

6. Ganjali, M. R.; Rezapour, M.; Norouzi, P.; Salavati-Niasari, M.; Electroanalysis 2005, 22, 2032.

7. Ganjali, M. R.; Qomi, M.; Daftari, A.; Norouzi, P.; SalavatiNiasari, M.; Rabbani, M.; Sens. Actuators, B 2004, 98, 92.

8. Ganjali, M. R.; Matloobi, P.; Ghorbani, M.; Norouzi, P.; Salavati-Niasari, M.; Bull. Korean Chem. Soc. 2005, 26, 38.

9. Ganjali, M. R.; Akbar, V.; Ghorbani, M.; Norouzi, P.; Ahmadi, A.; Anal. Chim. Acta. 2005, 531, 185.

10. Akhond, M.; Najafi, M. B.; Tashkhourian, J.; Anal. Chim. Acta 2005, 531, 179.

11. Mittal, S. K.; Kumar, S. K. A.; Sharma, H. K.; Talanta 2004, $62,801$.

12. Gupta, V. K.; Jain, S.; Chandra, S.; Anal. Chim. Acta 2003, 486, 199.

13. Ganjali, M. R.; Rahimi, M.; Maddah, B.; Moghimi, A.; Borhani, S.; Anal. Sci. 2004, 20, 142.

14. Ganjali, M. R.; Daftari, A.; Rezapour, M.; Poursaberi, T.; Haghgoo, S.; Talanta 2003, 59, 613.

15. Ganjali, M. R.; Norouzi, P.; Tamaddon, A.; Adib, M.; Sens. Actuators, B 2006, 114, 855.

16. Ganjali, M. R.; Rasoolipour, S.; Rezapour, M.; Norouzi, P.; Tajarodi, A.; Hanifehpour, Y.; Electroanalysis 2005, 17, 1534.

17. Ganjali, M. R.; Daftari, A.; Norouzi, P.; Salavati-Niasari, M.; Anal. Lett. 2003, 36, 1511.

18. Ganjali, M. R.; Ghesmi, A.; Hosseini, M.; Pourjavid, M. R.; Rezapour, M.; Shamsipur, M.; Salavati-Niasari, M.; Sens. Actuators, B 2005, 105, 334.

19. Zamani, H. A.; Ganjali, M. R.; Norouzi, P.; Adib, M.; Aceedy, M.; Anal. Sci. 2006, 22, 943.

20. Ganjali, M. R.; Pourjavid, M. R.; Rezapour, M.; Haghgoo, S.; Sens. Actuators, B 2003, 89, 21.

21. Ganjali, M. R.; Rezapour, M.; Pourjavid, M. R.; Haghgoo, S.; Anal. Sci. 2004, 20, 1007.

22. Ganjali, M. R.; Ravanshad, J.; Hosseini, M.; Salavati-Niasari, M.; Pourjavid, M. R.; Baezzate, M. R.; Electroanalysis 2004, 16, 1771 .

23. Shamsipur, M.; Hosseini, M.; Alizadeh, K.; Mousavi, M. F.; Garau, A.; Lippolis, V.; Yari, A.; Anal. Chem. 2005, 77, 276.

24. Zamani, H. A.; Ganjali, M. R.; Pooyamanesh, M. J.; J. Braz. Chem. Soc. 2006, 17, 149.

25. Ganjali, M. R.; Zamani, H. A.; Norouzi, P.; Adib, M.; Rezapour, M.; Aceedy, M.; Bull. Korean Chem. Soc. 2005, 26, 579.

26. Ganjali, M. R.; Zamani, H. A.; Norouzi, P.; Adib, M.; Accedy, M.; Acta Chim. Slov. 2005, 52, 309.

27. Zamani, H. A.; Rajabzadeh, G.; Firouz, A.; Ariaii-Rad, A.; J. Braz. Chem. Soc. 2005, 16, 1061. 
28. Zamani, H. A.; Rajabzadeh, G.; Ganjali, M. R.; Khatami, S. M.; Electroanalysis 2005, 17, 2260.

29. Zamani, H. A.; Malekzadegan, F.; Ganjali, M. R.; Anal. Chim. Acta 2006, 555, 336.

30. Zamani, H. A.; Rajabzadeh, G.; Ganjali, M. R.; Sens. Actuators, $B$, in press.

31. Zamani, H.A.; Abedini-Torghabeh, J.; Ganjali, M. R.; Electroanalysis 2006, 18, 888.

32. Kamata, S.; Bhale, A.; Fukunaga, Y.; Murata, A.; Anal. Chem. 1988, 60, 2464.

33. Teixeira, M. F. S.; Aniceto, C.; Fatibello-Filho, O.; J. Braz. Chem. Soc. 1998, 9, 506.
34. Zare, H.; R.; Memarzadeh, F.; Gorji, A.; R.; Ardakani, M.; M.; J. Braz. Chem. Soc. 2005, 16, 571.

35. Rostazin, T.; Bakker, E.; Suzuki, K.; Simon, W.; Anal. Chim. Acta 1993, 280, 197.

36. Ammann, E.; Pretsch, E.; Simon, W.; Lindner, E.; Bezegh, A.; Pungor, E.; Anal. Chim. Acta 1985, 171, 119.

37. Huster, M.; Gehring, P. M.; Morf, W. E.; Simon, W.; Anal. Chem. 1990, 63, 1330.

38. Umezawa, Y.; Umezawa, K.; Sato, H.; Pure Appl. Chem. 1995, 67, 507.

Received: April 6, 2006 Published on the web: August 30, 2006 